Gordan Janković ${ }^{1}$

Miloš Golubović

University of Niš, Faculty of Economics
SCIENTIFIC REVIEW ARTICLE doi:10.5937/ekonomika1903089J

Received: Jul, 12. 2019.

Accepted: September, 09. 2019.

\title{
OPEN INNOVATION IN SMALL AND MEDIUM-SIZED ENTERPRISES
}

\begin{abstract}
The subject of this paper is the so-called open innovation model and its importance for the development of small and medium-sized enterprises (in further paper SMES). The importance of the open innovation model for the development of SMEs, as well as identifying the major obstacles that stand in the way of wider application of this model in SMEs, is the aim of this research. The study used a variety of methods, such as induction and deduction, analysis and synthesis, as well as the method of description. SMEs are the driving force of economic development of the state, since they employ the largest part of the working-age population, significantly influence the formation of gross domestic product, solve the unemployment problem, raise the standard of living and strengthen the country's international competitive position through export business. By facilitating the process of intensive exchange of knowledge, tools and technology among certain economic actors, the concept of open innovation has contributed to improving the innovation of the SMEs sector as a key driver of the growth of their competitiveness in the knowledge economy. Innovation is a powerful tool for new SMEs to successfully enter the market and change the existing situation, enabling existing companies to maintain or improve their position on the market by improving their innovation.
\end{abstract}

Key words: innovations, small and medium enterprises, open innovation model.

JEL classification: $O 32$

\section{ОТВОРЕНЕ ИНОВАЦИЈЕ У МАЛИМ И СРЕДЫИМ ПРЕДУЗЕТИМА}

\begin{abstract}
Апстракт
Предмет истраживања овог рада је такозвани модел отворених иновација и юегов значај за развој малих и средњих предузећа (у даљем тексту МСП). Значај модела отворених иновачија за развој МСП, као и идентификовање најзначајнијих препрека које стоје на путу шире примене овог модела у МСП представљају ициь овог истраживачког рада. У истраживању су коришћени бројни методи, као што су: индукција и дедукција, анализа и синтеза, као и метод дескрипиије. МСП представљају покретач економског развоја државе, јер запошљавају највећи део радно способног становништва,
\end{abstract}

\footnotetext{
1 jankovic.gordan90@gmail.com

${ }^{2}$ milos.golubovic19@gmail.com
} 
значајно утичу на формирање бруто домаћег производа, ремавају проблем незапослености,подижу животни стандард и ојачавају међународну конкурентску позииију земље кроз извозне послове. Омогућујући процес интензивне размене знања, средстава и технологије између појединих економских актера, кониепт отворених иновација је допринео унапређењу иновативности сектора МСП као кључног покретача раста нихове конкурентности у економији знања. Иноващије су моћно средство за нова МСП да успешно уђу на тржиште и промене постојеће стање, омогућавајући истовремено и постојећим предузећима да унапређењем иновативности одрже или побољшају свој положај на тржишту.

Кључне речи: иновачије, мала и средња предузећа, модел отворених иновачија.

\section{Introduction}

Rapid technological development and the flow of information, increase of uncertainty as well are just some of the characteristics of a modern market that set new challenges to business entities. The market is globalizing, while the success of each of its stakeholders depends on many factors such as competitiveness, innovation, flexibility and so on. Competitiveness is the ability of the entity to ensure the continued growth and development. The competitiveness of an economy represents the competitive ability of economic actors, but also the business environment that competitiveness is ready to provide them. Porter (1990) says that a nation's competitiveness depends on the ability of its economy to innovate and improve. Innovations are based on the knowledge and play a key role in the growth and survival of the company. Economies based on knowledge are those which characterized the creation, dissemination and usage of knowledge and innovation. Innovations play a key role because they significantly affect all aspects of the knowledge-based economy. In the knowledge economy, the only economy that has the ability to efficient transformation of knowledge into innovation can achieve full employment and favorable long-term growth rate of GDP per capita (Atkinson and Ezell, 2014).

Most widely used model of business operations by the end of the last century, meant the innovation activities that have been largely determined by their own knowledge and available technology (Sungjoo et al., 2010). Realistically speaking, in such an environment, companies have not been too interested in changing the existing business model. Technological and organizational knowledge that are disposed, as a rule, are guarded as a trade secret (Greenhalgh and Rogers, 2011). The increasing importance and application of information technology, information and communication equipment, the increasing mobility of the workforce, changes in behavior and requirements of consumers as well as other features contemporary hyper-globalization led to the fact that the previous business model has less success. For this reason, at the beginning of this century, the open innovation model has become increasingly important. This model implies the process of intensive exchange of ideas, knowledge, technology and assets between companies, as well as an open innovation model implies the necessity 
of interconnecting business entities in order to reduce potential risks by definition of expensive research and innovation activities (Rahman and Ramos, 2011). Connecting becomes imperative of the growth and development of business entities in many hightech industries (Enkel, Gassmann and Chesbrough, 2009).

Economically developed countries and developing countries in recent years have been increasingly directed to the improvement of innovation, competing globally in attracting the most capable personnel and an increase in market share. Information flows and networks are spreading across borders, in a way that could not even imagine in the years before the Internet appeared, mobile phones and communication networks of different purpose and level (OECD, 2010).

The innovation potential of SMEs is of great importance for improving the competitiveness of the sector in which they operate, as well as the economy as a whole. Innovative SMEs are increasingly prominent source of knowledge within the framework of technological, sectoral and even national innovation system. In this regard, the identification of conditions and methods that enable the implementation of open innovation model are an important factor in the productivity growth and competitiveness of these companies (Grimaldi, Quinto and Rippa, 2013).

\section{Open innovation model}

Technological innovations which are connected and depend on each other over the past years have brought about major changes in some countries that are on the list of the most developed world economies. Innovation, as a materialized or commercialized idea, imposes the need for constant changes, especially changes in all areas of business (Jovičić and Jovičić, 2015). Countries not abundant in natural resources in today's conditions of globalization can possess exceptional economic potential, thanks to the ability to commercialize knowledge in innovation (Mroczkowski, 2012). Many experts in the field of innovation and entrepreneurship are considered to be the period from mid to the end of the last century changed five generations of innovation. The first four generations of innovation belong to the field of closed innovation since all companies in this period financed innovation from its own resources. Unlike them, the fifth generation, which is known as the generation of open innovation, companies provide financing funds for innovative activities from different sources, both their own, and others. The model of closed innovation was based on several basic principles (Chesbrough, 2006):

1) investing in their own research and development, the company provides good prospects for hiring the most capable personnel for the job,

2) in order to make a profit on the basis of research and development, the company must complete the entire process of reaching ideas to their commercialization in innovation,

3) companies need to control their own property and to prevent competitors from making profits on that basis,

4) enterprises with new ideas and products are winning in the competitive match.

Open innovation model is an integral part of the modern open business model of the company. This concept was first introduced Chesbrough (2006) when he suggested 
that companies from different sectors, especially in the field of high technologies (eg, information technology, mobile phones, computers, medicine, biotechnology, nanotechnology, robotics engineering, etc.) have significantly changed the way of innovation by changing their innovation from a model of closed innovation to the socalled open innovation model. From the first moment this transition was announced from a closed to an open innovation model, attracted a great attention of researchers and practitioners in the field of innovation.

This model efficiently generates innovation since it combines multiple talents, creativity and more new ideas than would be possible even in a large corporation. Good ideas and inventions come from various unexpected places, from customers, suppliers, partners, joint ventures, and even the public (Smith, 2010). It can freely be said that the open innovation model has markedly changed the way innovations in companies in this century (Chesbrough, 2006). A number of scientists believe that this model represents something more than simply use other people's ideas and technology. According to them, this model represents a shift in the use, management, employment and the creation of intellectual property in the knowledge economy (West and Gallagher, 2006).

The fifth generation of innovation occurs in a globalized environment where knowledge through an alliance (primarily using the Internet) have become widely available and where individual companies (before all SMEs) do not have enough resources to independently implement the necessary research and development activities. The concept of open innovation implies that companies can use external ideas (knowledge and technology) in almost the same way as internal ideas in order to commercialize innovative ideas on the market. In this model, SMEs can continue to initiate and use innovations within the company, but at the same time they can rely on some other ways to bring the idea to the market, while at the same time have the benefits of external knowledge (Vanhaverbeke, 2006).

There were several factors that led to the development and application of the concept of open innovation. Technological intensity of production, which has increased in many areas has led to the fact that even a company with advanced research and development sector are not able or unwilling to rely on their own technological development (Gassmann, 2006). The innovation process is becoming increasingly complex while solving a large number of complex problems involves an interdisciplinary approach to research which usually leads to higher costs and more significant risks in the innovation process (Howells et al., 2003). For this reason, companies are often determined that some researches which are less important to them are entrusted to other organizations.

\section{Open vs. closed innovation}

The basic characteristic of the business by the end of the twentieth century is a closed innovation process. Innovative activities of the company were carried out only within the company based on available knowledge and technologies, and intellectual property was a business secret. The companies were not ready to exchange their innovation results with other companies, so that the exchange of information and cooperation in the innovation transition was not seen as a potential tool for creating a competitive advantage on the market. The basic assumption a model of closed innovation is that successful innovation 
requires control. It proceeded from the principles of self-sufficiency, that is, on reliance on one's own strengths. This internally orientated innovation method, Chesbrough, called the model of closed innovation. According to this approach, successful innovation arises as a result of innovative business ventures within the company itself, and for these reasons, firm control over these ventures is necessary in order to facilitate management. Business are expected to come up with ideas and develop their own research, turn them into specific products and services, sell, service, monitor and analyze them throughout the life cycle of the product.

Figure 1 presents model of closed innovation which we will explain in further paper.

Figure 1: Model of closed innovation

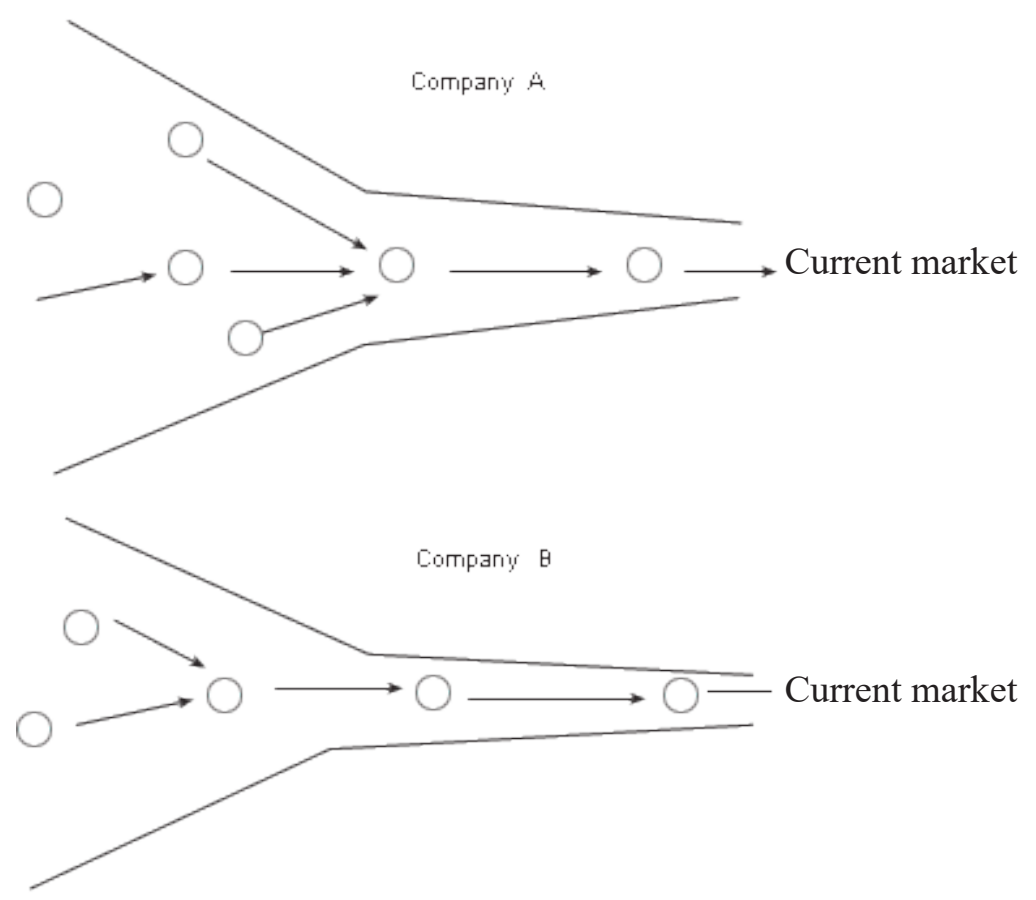

Source: Chesbrough, H., (2006), p. 31

Figure 1 shows this model of closed innovation for managing ID. The solid lines show the boundary of each firm, A and B. Ideas flow into each firm, on the left, and flow out to the market on the right. They are screened and filtered during the research process, and the surviving ones are transferred into development and then taken to market.

Figure 1 also shows the knowledge landscape that arose from the pattern of deep, vertically integrated ID organizations such as firm A and firm B, and the impoverished landscape that surrounded them. Although there were many ideas, few of them were available outside the walls of these firms.

Consumers are very important for the development of open innovation model. Many of them are innovatively oriented. By seeking to improve their consumer demands, they at the 
same time improve existing products and services, and so they become innovators (Bogers, Afuah and Bastian, 2010). The concept of open innovation is extremely suitable for use in new technology sectors where a large number of enterprises (a growing number of SMEs) also have products and services in their offer. By striving to maintain their position in an extremely complex and globalized market, companies create separate organizational units that monitor open innovation that focuses on innovation activities outside their business circle.

According to Chesbrough (2006), the concept of open innovation is based on the following principles:

1) the company does not have to employ top-level personnel, it is enough to cooperate with them only,

2) internal innovation activities are necessary to confirm some of the important values that can be created by external innovation efforts,

3) in an effort to win the competition, new business models are more important than the market itself,

4) in order to gain an advantage over competition, the company does not have to come up with the best ideas, but it is more important to use the best internal and external ideas.

Figure 2 depicts the knowledge landscape that results from the flow of internal and external ideas into and out of firms A and B within open innovation model.

Figure 2: Open innovation model

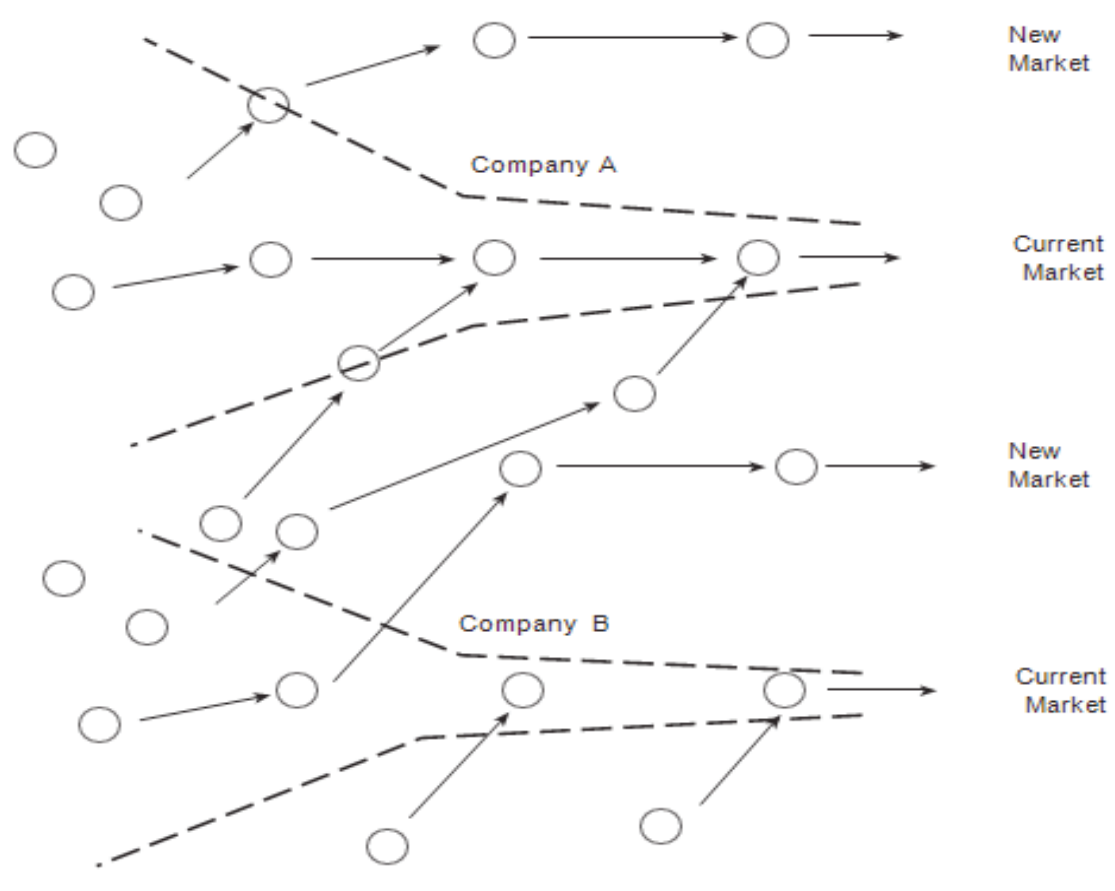

Source: Chesbrough, H., (2006), p. 44 
Ideas abound in this environment, not only within each firm, but also outside the firms. These ideas are available to be used, and often the people who created them are similarly available for hire. The availability and quality of these external ideas change the logic that led to the formation of the centralized ID silos of the closed innovation model, which is presented in figure 2 .

The concept of open and closed innovation, even though they were created on the same platform, are fundamentally different. Closed innovation refer to processes that are limited only to the use of internal ideas, knowledge and other innovation resources within the enterprise. In contrast, the concept of open innovation implies that companies need to use external ideas, knowledge and other innovation resources in the same way as internal ideas. De Jong (2008) points out that in the open innovation model, it is clearly seen how the input and downstream knowledge flows turn into economic value and how the accelerated product development creates ideas leading to the development of the value chain.

\section{The significance of open innovation model in the development of SMEs}

In today's globalized world, the key to the success of a company, including SMEs, depends not only on having the latest knowledge. The core of success is in the right combination of existing knowledge with available external knowledge and their valorization in innovation. In order for modern companies to use the knowledge and information that comes from their environment, they must constantly improve their own knowledge, and therefore their own innovations. External knowledge does not have a value for the enterprise unless they do not connect with internal knowledge. The quality of the acquired network of internal and external knowledge determines the quality and efficiency of the innovation potential of the company (Cvijić, Borocki and Lalić, 2012). The ability of companies to reach external sources of knowledge depends on the ability of the supplier, ie on the level of development and quality of the external base of innovative knowledge.

Due to mobility in the labor market, employees can leave the company in which they work and choose one of two options, to switch to another company or to create their own. If they have opted for another option, funding may be a form of joint venture or self-financing. In this case, there is a great possibility that the employee, who left the enterprise, bring with him the innovation potential of the previous company. This would mean that the new enterprise would gain new knowledge or new innovation potential (West and Gallagher, 2006).

The increasing presence of private funding creates a number of risks for companies that heavily rely on internal innovation because the growing opportunities for joint ventures increase the inclination of individual employees to establish their own or join existing start-ups enterprises (Rigby and Zook, 2002). The main reason for this would be because employees believe that newly start-ups companies offer a more favorable relationship in terms of risk and earnings.

Innovative-active enterprises are enterprises with innovative activities in the current period of extension including ongoing and abandoned innovation activity. Potentially innovative companies are a kind of innovative active enterprises, which have 
made innovative efforts, but have not achieve innovative results (OECD, Eurostat, 2005).

There are other ways of defining and dividing innovative companies depending on the needs of the research. The division of an enterprise towards innovation can be used to determine the percentage of enterprises (by size, sector, country or in some other way) that represents each of the four types of innovation, or the percentage of enterprises that have implemented combined innovations, such as product innovation and innovation in marketing or process innovation and organizational innovation. The division into an innovative status may also contain other data, such as information on innovators. The company may have innovation activities in the observed period, but it does not actually realize the innovation. In the observed period, innovation activities may be:

- successful and result in the emergence of innovation,

- current and to include all innovative ongoing activities that have not yet led to the implementation of innovation,

- deserted or abandoned innovative activities before applying innovation.

SMEs represent a very diverse group of companies in terms of innovative capacities, innovative activities and innovation results. According to this, all the SMEs can be classified into one of the following four groups:

- Innovation leaders

- Leading users of information

- Potential innovators

- $\quad$ Non-innovative SMEs

Table 1: Distribution of SMEs depending on available innovation capacity

\begin{tabular}{|c|c|}
\hline Innovation leaders & Leading innovation users \\
\hline Potential innovators & Non-innovative SMEs \\
\hline
\end{tabular}

Source: OECD, 2000, p. 20.

Innovation leaders are SMEs that are focused on innovation and based their development and business on new superior products and services.

The second group of innovative SMEs consists of enterprises that are the first beneficiaries of innovation (OECD, 2000). Although companies from this group do not have the ability to be innovative leaders, their survival is based on the rapid application of the latest knowledge and technologies. Enterprises from this group can be divided into two main subgroups: SMEs with sufficient ID capacity for self-innovation and SMEs that rely more on other ID capacities.

The third group consists of potential innovators. These are companies that are not too innovative, they have been in existence for a number of years, actively following the most significant innovations and most often doing business in traditional activities where technological changes are not too fast.

The fourth group consists of SMEs that have no ambitions and possibilities to innovate. These are non-innovative enterprises that are old, but well-positioned and most often those are enterprises that operate in the field of low-tech manufacturing.

Figure 3 depicts impact of different size enterprises to growth in value added and employment in Europian Union. 
Figure 3: Contribution of different size class enterprises to growth in value added and employment in the EU-28 non-financial business sector in 2017

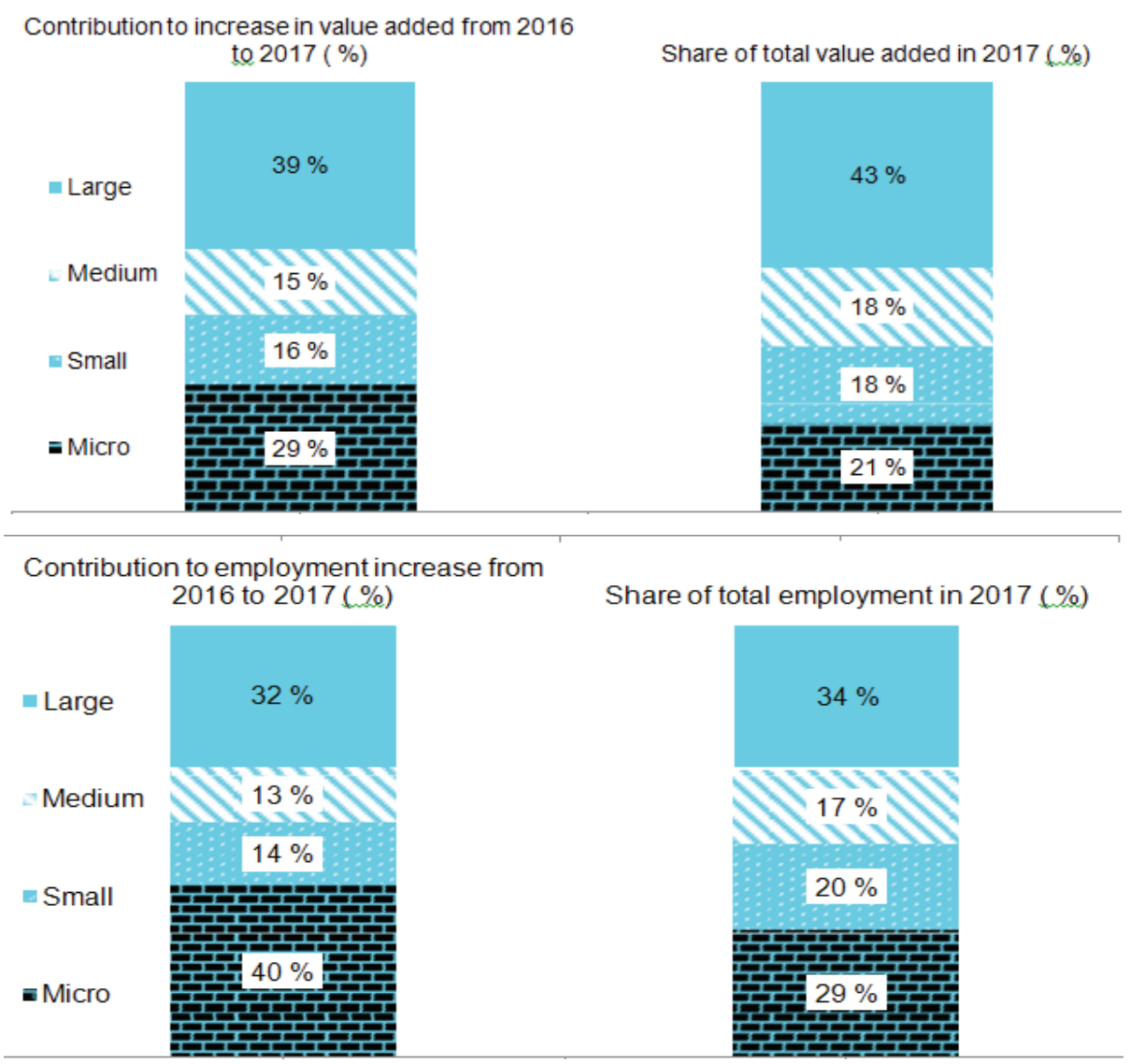

Source: Eurostat, National Statistical Offices, DIW Econ

Within the SME sector, micro EU SMEs made an exceptionally large contribution in 2017 . They accounted for $29 \%$ of the increase in the value added generated in the EU non-financial business sector, while their share of total value added in the sector was only $21 \%$ (Figure 3 ). In contrast, SMEs made proportionately lower contributions to the growth in value added in the EU non- financial business sector in 2017.

A successful open source innovation strategy for SMEs should find creative ways to use internal innovation and available external innovations that contribute to enterprise development. Competent research suggests that the concept of open innovation improves the innovative performance of SMEs (Hossain, 2015). These companies have certain advantages in the innovation process that makes them a suitable networking partner, as they are usually less bureaucratic and, generally speaking, have a higher motivation to be more successful than large companies (Pullen et al., 2008). Benefits of networking SMEs include: innovative chances, lower transaction costs, cost sharing, and higher productivity. 


\section{Restrictions on the application of open innovation in SMEs}

SMEs sector acts as an integrator of the entire innovation system (Cvetanović and Sredojević, 2012). Since in the knowledge economy, SMEs operate in a global environment, it is necessary to establish cooperation with larger enterprises in order to create better opportunities and greater utilization of their capacities, as well as with other SMEs from the same or different activities, as well as with research centers, institutes, laboratories, independent researchers, universities and all other entities that can contribute to their innovative development. Increasing global competition and rising costs of research and development activities are forcing SMEs to cooperate with external partners in order to present new products and services on the market ahead of their competitors. At the same time, innovation will be more accepted if users of products and services, whether it is about other businesses or individual consumers, are increasingly becoming involved in the innovation process (De Backer, 2008).

A successful open innovation strategy for SMEs should find creative ways to use internal innovation and available external innovations that contribute to enterprise development. Michael and Palandian emphasize that SMEs have certain advantages in the innovation process that makes them a suitable linking partner, as they are usually less bureaucratic and, in general, often have a higher motivation to be more successful than large companies. On the other hand, there are problems and constraints that make it difficult to apply the open innovation model to SMEs.

SMEs have a shortage of resources, so that their planning period relates most in the medium term. The inability of real long-term planning significantly reduces the possibility of accessing small enterprises with external research results. SMEs are not always easy to enter a sustainable value chain in the market because they focus only on short-term market promotions. Very often small businesses do not even have well-developed medium-term demand planning due to limited resources and shortcomings of the necessary network of contacts. The problem may also be the time-mismatch of the framework of the research of external partners (e.g.. universities) with the real needs of SMEs that small enterprises often do not allow aggressive market presence at the right time and with the right product.

Table 2: Obstacles with open innovation for SMEs

\begin{tabular}{|c|c|c|c|c|c|}
\hline \multicolumn{2}{|c|}{ obstacles } & Internal & obstacles \\
\hline Supply & Request & Environment & Resources & Culture & System \\
\hline $\begin{array}{c}\text { Technological } \\
\text { information }\end{array}$ & Consumers needs & Legal regulation & $\begin{array}{c}\text { Lack of internal } \\
\text { funds }\end{array}$ & $\begin{array}{c}\text { Attitude top } \\
\text { management related } \\
\text { to risk }\end{array}$ & $\begin{array}{c}\text { Out of date } \\
\text { accounting } \\
\text { system }\end{array}$ \\
\hline Raw materials & $\begin{array}{c}\text { Consumer } \\
\text { perception of the } \\
\text { risk of innovation }\end{array}$ & Athenian policy & Technical expertise & $\begin{array}{c}\text { Employee Resistance } \\
\text { to Change } \\
\text { (Innovation) }\end{array}$ & \\
\hline & $\begin{array}{c}\text { Limitations on the } \\
\text { domestic market }\end{array}$ & $\begin{array}{c}\text { Measures for } \\
\text { implementing } \\
\text { the policy }\end{array}$ & Time management & & \\
\cline { 2 - 6 } & $\begin{array}{c}\text { Limitations on } \\
\text { the international } \\
\text { market }\end{array}$ & & & & \\
\hline
\end{tabular}

Source: Rahman and Ramos (2011), p. 480.

Hanna and Welsh (2002) point out that in relation to large enterprises, SMEs have 
a number of typical problems related to their process of innovation, especially from the stage of development to the stage of commercialization. SMEs have a greater problem with: financing of the research process, lack of qualified staff and fewer opportunities for replacing the relevant products on the market, limited product placement, etc. In addition to these, there is a number of other internal and external barriers that reduce and impede the successful implementation of the open innovation model in SMEs. However, these factors do not diminish the importance and necessity of applying the open innovation model for successful innovative development of modern SMEs.

\section{Conclusion}

Open innovation model has been developing since the end of the twentieth century. It reflects the endeavor to exploit the available resources of knowledge and creativity. The open innovation model prefers the growing mobility of labor, especially highly creative. It accepts the spread of business risks and start-ups of entrepreneurial ventures, which is particularly suited to the development of the SMEs sector. The main advantages of the open innovation model are the wider possibilities of applying innovations, both of their own and those coming from the environment. This suggests a business model that is based on the determination that cooperation is better than the competition. The open innovation model offers great opportunities to all actors including SMEs, but at the same time they also carry great risks of their market survival. There are limitations that make it difficult to apply the open innovation model to SMEs. These companies have a shortage of resources, so their planning period relates most in the medium term.

The previously explored generation of innovations in any case can't be treated as final. On the contrary, with a great deal of confidence, it can be said that creativity and innovation will be the most valuable, both personal and group legitimacy and the most reliable "ticket for the future" for every future citizen of this single country. Therefore, some future analysts of these subjects will talk about the sixth, seventh, eighth and who knows to which generation of innovation.

\section{References}

Atkinson, R., Ezell, S., (2014). Ekonomika inovacija - utrka za globalnu prednost. Mate, Zagreb;

Aničić, J., Aničić, D., \& Vasić, N. (2017). Entrepreneurship development and financial performances in SMEs sector in Serbia. Ekonomika, 63(4), 29-39.

Bogers M., Afuah A., Bastian B., (2010) Users as Innovators: A Review, Critique and Future Research Directions, Journal of Management;

Chesbrough, H., (2006) Open Innovation: The New Imperative for Creating and Profiting from Technology, Harvard Business School Press, Boston;

Cvetanović, S., Sredojević, D., (2012), Konceptnacionalnog inovacionog sistema I konkurentnost privrede, Ekonomske teme, Ekonomski fakultet u Nišu, Niš, no 2, 167-185; 
Cvijić, M., Borocki, J., Lalić, D., (2012) Otvoreni modeli inovacija, Inovacije $i$ preduzetništvo: alati za uspeh na tržištu EU, Univerzitet Singidunum, Fakultet za ekonomiju, finansije i administraciju i Centar za promociju nauke, Beograd;

De Backer, K,. (2008), Open innovation in global networks, OECD Publishing;

De Jong, J. P. J., Vanhaverbeke, W., Kalvet, T., Chesbrough, H., (2008), Policies for open innovation: Theory, framework and cases, Final report for a Research project funded by VISION Era-Net, Helsinki: Finland

Enkel, E., Gassmann, O., Chesbrough, H., (2009) Open R\&D and open innovation: Exploring the phenomenon. R\&D Management;

Gassmann, O., (2006), Opening up the innovation process: towards an agenda, R\&D Management;

Greenhalgh, C., Rogers, M., (2011) Innovation, Intellectual Property and Economic Growth, Princeton University Press;

Grimaldi, M., Quinto, I., Rippa, P., (2013) Enabling open innovation in small and medium enterprises: A dynamic capabilities approach, Knowledge and Process Management;

Hanna, V., Walsh, K., (2002) Small firm networks: A successful approach to innovation? R\&D Management;

Hossain, M., (2015) A review of literature on open innovation in small and mediumsized enterprises, Journal of Global Entrepreneurship Research;

Howells, J., James, A., Malik, K., (2003) The sourcing of technological knowledge: distributed innovation processes and dynamic change, R\&D Management, Vol. 33. no. 4, pp. 395-409;

Jovičić, M., Jovičić, A., (2015) Inovacije i konkurentska prednost, Anali Ekonomskog fakulteta u Subotici, Subotica, Vol. 51. No. 33, pp. 193-202;

Mroczkowski, T., (2012) The new players in life science innovation: best practices in $R \& D$ from around the world, FT Press, New Jersey;

OECD, (2000) Enhancing the competitiveness of SMEs in the global economy: Strategies and policies, Workshop 1, Enhancing the competitiveness of SMEs through innovation, Conference for Ministers responsible for SMEs and Industry Ministers, Bologna, Italy, 14-15 June 2000;

OECD and Eurostat, (2005) Oslo Manual - Proposed Guidelines for Collecting and Interpreting Technological Innovation Data, OECD, Paris;

OECD, (2010) Assessing the Effects of ICT in Education Indicators, Criteria and Benchmarks for International Comparisons: Indicators, Criteria and Benchmarks for International Comparisons, Ed. Scheurmans, F., Pedro, F., Joint Research Centre- European Commission, OECD.

Porter, M., (1990), Competitive Advantage of Nations, New York: Free Press;

Pullen, A., De Weerd-Nederhof, P., Groen, A., Fisscher, O., (2008) Configurations of external SME characteristics to explain differences in innovation performance, Proceedings of the High Technology Small Firms Conference 2008, Twente University, Netherlands; 
Rahman, H., Ramos, I., (2011) Open Innovation in SMEs: From Closed Boundaries to Networked Paradigm, Issues in Informing Science and Information Technology, University of Minho, Guimaraes, Braga, Portugal;

Rigby, D., Zook, C., (2002) Open-market innovation, Harvard Business Review;

Simonović, Z., Ćurčić, N., \& Miletić, V. (2017). Some problems of small and medium enterprises in Serbian agriculture. Anali Ekonomskog fakulteta u Subotici, (37), 57-69.

Smith, D., (2010) Exploring Innovation, McGraw-Hill;

Sungjoo, L., Gwangman, P., Byungun Y., Jinwoo, P., (2010) Open innovation in SMEsAn intermediated network model, Research Policy Vol. 39. no. 2, pp. 290-300;

Vanhaverbeke, W., (2006) The interorganizational context of open innovation. In: Chesbrough, H., Vanhaverbeke, W. and West, J. (Eds.). Open innovation: researching a new paradigm, Oxford;

West, J., Gallagher, S., (2006) Challenges of open innovation: the paradox of firm investment in open-source software, R\&D Management. 